\title{
A Re-Evaluation of the Application of Keynesian Economic Theory to Classical Athens
}

\author{
By Kenneth Moore*
}

\begin{abstract}
A cornerstone of Keynesian economic theory is that the prosperity of the nation depends heavily on the amount that the state expends on the general welfare and on public works in particular. This paper will consider historiographical arguments around the application of this theory to Classical Athens of the 5th-4th c. BC. This example has been used to illustrate how, at times in which public outlays were high, the state also experienced significant prosperity, even reaching the apex of its power and dominance. And, conversely, when the amount of money expended by the state shrank and wealth was concentrated in fewer hands, it suffered diminished status. This amounts to a retrospective application of Keynesian economics that will, hopefully, illustrate a key fact of economic practice devoid, as far as possible, from the overarching ideologies that affect such theories in modernity. This is not an uncontroversial approach and the aim of this article is to examine previous attempts to apply this theory along with the criticisms of them.
\end{abstract}

It is tempting to make recourse to modern economic theories in order to explain historical events in antiquity. This especially applies to instances, both in Classical Athens and ancient Rome, where vast government expenditures appear to have produced an economic "boom" affecting general prosperity in the short- and long-term. Keynesian economics in particular seem most appropriate to explain such phenomena. Keynes favoured increased state expenditures and lower taxation in order to stimulate demand (thus "demand-side economics"), and thereby employment, which were considered to have pulled the global economy out of the Great Depression of the 1930s. ${ }^{1}$ Afterwards, the term "Keynesian economics" was used to refer to the concept that optimal economic performance could be achieved, with economic slumps thus avoided, by influencing "aggregate demand through activist stabilization" and economic interventionist policies undertaken by the government. ${ }^{2}$

A number of theorists since Keynes have sought retrospectively to apply this theory, or some version of it, to ancient societies as illustrative examples of the process working in practice. Others have rejected that approach on a number of theoretical grounds. In particular, M. I. Finley and the "primitivists" (after Max Weber) have argued that no real comparison of this type can or should be drawn. The aim of this article is to examine some seminal instances of these and, through historiographical analysis, determine their relative merits or lack thereof. Due to limitations of space, the example of Periklean Athens and its immediate aftermath will be the primary subject of this inquiry; although, the case of Rome in the early Principate would also be applicable. Structurally, this article will examine the facts, as we understand them, of

\footnotetext{
${ }^{*}$ Senior Lecturer, University of Teesside, UK.

1. See J. P. Neary and J. E. Stiglitz, "Toward a Reconstruction of Keynesian Economics: Expectations and Constrained Equilibria," The Quarterly Journal of Economics, 98. Supplement (1983): 199-228, for a fuller explanation of this theory.

2. "Keynesian Economics," Investopedia, http://bit.ly/2zaY1Sr.
} 
Athens' economic prosperity under Perikles, move on to consider scholars who have sought to understand this in terms of modern economic theory and then engage with criticisms of such an approach. Have they formed a biased reception of Classical Athens through the distorting lens of modern theory? How have current events shaped such interpretations? Could there be something worthwhile and instructive in retrospectively applying these theories to the ancient past?

Firstly, let us consider the "facts on the ground" as we have them. In $454 \mathrm{BC}$, the Athenians transferred the treasury of the Delian League from Delos to Athens, ostensibly for reasons of security. The allies (soon to be the "subjects" of Athens) had mostly paid money into this treasury rather than provide ships, men and materiel for the common defence of Hellas against the Persians since Athens, at the head of a trading empire, was better positioned to produce them than her poorer relations. The $5^{\text {th }}$ century, Athenian historians Thucydides and Xenophon provide information on the income from the League. ${ }^{3}$ Thucydides, alluding to Athenian imperial ambitions, further describes this situation as follows:

The Athenians also arranged for the other members of the League to pay their share of the expenses in money instead of in ships and men, and for this the subject city-states had themselves to blame, their wish to get out of rendering service which would cause most to have to leave their homes. Thus while Athens was increasing her navy with the funds they contributed, a revolt always found itself without enough resources or experienced leaders for war. ${ }^{4}$

In addition to the obvious economic stimulus that this large-scale military expenditure entailed, the relationship between Athens and her "allies" allegedly required non-Athenian citizens to come to Athens directly for any legal proceedings arising between them and the Athenians. According to a $4^{\text {th }}$ century satirical treatise known only as pseudo-Xenophon's Old Oligarch:

...they force the allies to sail to Athens for judicial proceedings...[b]ut they reason in response that the Athenian people benefit from this... [f]irstly, from these legal deposits they receive their dikastic pay throughout the year...the one per-cent tax in the Peiraeus brings in more for the city; secondly, if anyone has lodgings to rent, he does better, and so does anyone who lets out on hire a team of animals or a slave; further, the heralds of the assembly do better when the allies are in town. ${ }^{5}$

3. Xen. Anab. VII.1.27 notes 1,000 talents in total revenue, and Thuc. II.13.3 notes 600 talents from imperial sources.

4. Thucydides, History of the Peloponnesian Wars, I.99. See too Pseudo-Xenophon, the Old Oligarch, II.11-13, for further commentary on Athens' trading empire as a source of material prosperity.

5. Pseudo-Xenophon, the Old Oligarch, I.16-18; on the one per-cent tax, see Aristophanes, Wasps, 658. This was evidently some kind of customs duty. 
Despite the provenance of the source, the facts revealed are illuminating. These judicial proceedings are, however, not unproblematic and their precise nature has been debated. ${ }^{6}$ It does seem clear that the court cases resulting from their League, alongside the augmented stipend for jurors by Perikles, amounted to a ready source of income for Athens' citizens in addition to the allies' regular contributions paid directly to the state, with positive, financial knock-on effects. This is above and beyond the increased revenues resulting from Athens' position which, following a decree of the Assembly under Perikles, encouraged all Greeks to regularly send deputations to that city for diplomatic purposes, with the attendant costs borne by the foreign citystates. $^{7}$

Indeed, the amount of cash flowing into Athens produced a sufficient surplus that some clever politicians, such as Perikles, opted to spend on infrastructure and ornamentation of the city and subsidies to ordinary citizens rather than just on the common defence. Thucydides was critical of these expenditures; but, we are told that Perikles put the matter before the Assembly and "they cried out with a loud voice and bade him take freely from the public funds for his outlays", and then proceeded to ostracise his chief critic, Thucydides, in $422 . .^{8}$ This, in turn, promoted wide-scale employment with the consequent increase in tax revenues for the polis. Perikles also reportedly shared the wealth of empire with Athenians and "won their favour by distributions of money and proposed allotments of conquered lands". Thucydides was not alone in criticising Perikles' fiscal policy. Plato too rejected it as his crowning glory, for philosophical reasons, saying, "as I am well aware, Perikles made the Athenians slothful, garrulous and grasping by initiating the system of public fees". ${ }^{10}$ That which does seem apparent from this though, whatever the moral objections of his detractors, is that Perikles' policy of increased state spending corresponded with the height of Athens' financial and political prosperity.

Some further economic background is necessary here. Athens appears fairly unique amongst ancient poleis, and not only for being the first developed democracy. It comes across as surprisingly modern, in many respects, as an urban-based consumer society. As Hansen has effectively demonstrated, Athens was a "consumer city", if not purely in the ideal form as defined by Max Weber. ${ }^{11}$ As indicated, it was the hub of a trading empire, attested by Perikles famous "Funeral Oration" in Thucydides (II.38.2), although not a major exporter of goods, with one exception, insofar as we can tell. The $4^{\text {th }}$ century orator Demosthenes was reported to have inherited an arms

6. For discussion of the controversial problem of the judicial relations of Athens and her allies, see G. E. M. de Ste. Croix, "Notes on Jurisdiction in the Athenian Empire," Classical Quarterly, N.S. 11.1 (1961), 94 ff. The Athenians' own account of their alleged litigiousness with regard to the allies may be found in a difficult passage of Thucydides at I.77 ff.

7. Plutarch, Life of Perikles, XVII.1.

8. Plutarch, Life of Perikles, XIV.2.

9. Plutarch, Life of Perikles, XXXIV.1-2.

10. Plato, Gorgias, 515e.

11. M. H. Hansen, Polis: An Introduction to the Ancient Greek City-State (Oxford: Oxford University Press 2010), 92-93. 
manufactory from his father, and we hear of others too (discussed below), which suggests that at least one prominent export was weapons for warfare. ${ }^{12}$ Citizens lived in both town and country, engaging in subsistence farming, albeit not enough to supply the population's needs, along with considerable mercantile activities, especially sea-based trade through the port of the Piraeus. The hinterland of Attika was approximately 2,500 sq/km and this held a population in the Classical era of somewhere between 250,000 and 300,000 people, with 90,000 to 100,000 living in the urban centre. ${ }^{13}$ Some of the people who resided in the city itself were farmers, going out to the countryside to work; some were landowners who rented out their properties either in the city or in the countryside. Many would have owned or worked for businesses of various types dealing with trade or with the production and maintenance of goods relating to trade and/or the military, especially concerning shipbuilding and shipping. There was a form of banking, loans made with interest for business ventures and an early form of insurance for merchants known as "bottomry" (or "catastrophe bond"). ${ }^{14}$

These and other qualities make Classical Athens a seemingly ideal subject on which to apply modern economic theory in retrospect-granted, with certain caveats and limitations. Indeed, it has been tempting for many to do so. The "New Deal" of U.S. President Franklin Delano Roosevelt has invited parallels with the reforms of the $6^{\text {th }}$ century Athenian statesman Solon - both men used extraordinary political powers to push through economic acts designed to deal with apparently similar crises. And clearly there was something "in the air" in the late $19^{\text {th }}$ and early- $/$ mid- $20^{\text {th }}$ centuries that seemed to beg such comparisons. Prominent scholars of Greek history such as Eduard Meyer, Robert von Pöhlmann, and Ulrich von WilamowitzMöllendorff have arguably gone to an extreme in the wholesale application of the terminology of modern capitalism to the economics of ancient Greece. In fact, the very title as well the arguments of von Pöhlmann's treatise, The History of the Social Question and of Socialism in the Ancient World, evinces a tendency to interpret ancient conditions in terms of the complex and highly integrated system of capitalism contemporary with his lifetime. ${ }^{15}$ Other scholars have been quick to criticise this approach while some have continued to seek its refinement.

There have been a number of objections to this parallelism and the origins of this tradition can be traced to "the Carl Bücher or primitivist" side of the so-called "oikos controversy" in the last decade of the $19^{\text {th }}$ century. ${ }^{16}$ This approach stressed the "embeddedness" of ancient economic activity. Greek life was typically situated within small city-states, they argue, which were primarily agricultural in nature; whereas, the imperialistic expansion

12. Plutarch, Life of Demosthenes, IV.

13. M. H. Hansen, Polis, passim.

14. G. Corby, "Ancient Greek insurance scams", last modified February 5, 2009, http://bit.ly/2Blj1aP

15. L. R. Lind, "Economic Man in Ancient Athens," The Classical Journal 35, no. 1 (Oct. 1939): 29

16. M. Nafissi, "Class, Embeddedness, and the Modernity of Ancient Athens," Comparative Studies in Society and History 46, no 2 (Apr., 2004): 380. 
we find in connection with capitalism elsewhere has been chiefly political in its motives. There was urbanization such as grew up in Hellenistic and Roman times as well as in Classical Athens; but, they argue that the Greek polis did not officially encourage a trade industry at the political level, and interfered with such activities only to maintain the food supply from abroad as necessary. The objectors maintained that the jealous separatism of regions tended to concentrate industry within individual city-states. There was no merchant marine, according to Lind in his 1939 work addressing these very issues, along with no reliable, universal currency for trade. ${ }^{17}$ Yet these and other such claims are not un-problematic, as shall be demonstrated.

This alleged disconnect between political activity and the economy was seen in no small part as a philosophical one. Lind ranges through these points mentioned above, giving his final summation on the matter to the effect that that the main difference between ancient Greek economics and modern is:

...the social and aesthetic attitude toward trade and industry. It will surprise the modern uninformed inquirer; it will shock that vast bourgeoisie who have been accustomed by more than a century of "big business" to look up with worshipful awe to the captain of industry, to learn that the Greeks despised businessmen. They were interested in humanity, art, letters, and the full expression of the personality; not in money and machines. ${ }^{18}$

He supports this somewhat romanticised position with recourse to Plato's Republic 371, alongside Aristotle's Politics (i.11.5), as evidence for such an attitude. Certainly, the position of Plato's speakers in the Laws is contrary to capitalistic expansion and opportunism as the modern world understands them. ${ }^{19}$ But one might well ask whether the views of elite philosophers actually reflected the zeitgeist of a whole civilisation. The interpretation of Athenian slavery, in particular, as a kind of "embedded" economic activity has in recent years been heavily criticised, largely dependent as it is on Aristotle. ${ }^{20}$ One of Lind's other objections to this parallelism, namely that no Greek city-state was economically self-sufficient, seems counterintuitive since no modern nation-state may truly be said to be so. Indeed, he comes across as having an "axe to grind" which clearly exerts a particular inflection on his arguments.

Like a number of opponents to drawing such parallels, Lind had essentially adopted a "primitivist" approach to ancient Greek economics which precludes comparison with more modern theories and systems. The strongest objections originated with social scientists and scholars whose conclusions were based in part on comparative models. The work of Moses Finley, beginning in the early 1950s, established this new orthodoxy, then codified with the term economic "primitivism". Grounded in the studies of Max Weber and other

17. Lind, "Economic Man in Ancient Athens": 29-30.

18. Ibid.

19. See K.R. Moore, Sex and the Second Best City (Routledge: New York: 2005), passim.

20. Nafissi, "Class, Embeddedness", passim. 
social theorists, Finley et al. asserted that, in terms of "operation and values", the ancient economy was an "embedded" phenomenon. ${ }^{21}$ It was, they said, fundamentally agrarian in character with ancient economic activity being directed by a complex array of social and political institutions and customs, with economic behaviour shaped by familial, religious and socio-political values. $^{22}$ In re-evaluating their claims, Burke argues that there had been significant growth in actual economies, as well as in thinking about economics more generally, from the Archaic Age to the Classical; he admits that there "is disagreement, however, about what this evidence signifies". ${ }^{23}$ What is clear is that there was an emerging middle class during this period, with all of the standard economic activity that such implies, albeit limited by ancient technology and trade networks, and that the Athenian polis' political power and dominance increased in proportion to its economic strength.

In no small part, the rejection of contemporary economic models being applied to ancient Greece comes down to a matter of definition. During the post-colonial era following the Second World War, ancient historians had primarily regarded imperialism as an almost exclusively political and military activity in ancient Rome, Greece and elsewhere, with economic factors as secondary at best. ${ }^{24}$ This approach often ignored economic aspects of imperialism which figured prominently in the Delian League/Athenian Empire but which are seen in the globalised world of the early $21^{\text {st }}$ century as being highly relevant in connection to military and political power. Trade and commerce were integral to Athenian hegemony. Indeed, the issue of universal currency seems apparent, contrary to Lind's objections mentioned above, since the standardised Athenian Owl drachmas, and later tetradrachmas, were developed specifically for trade, which implies a larger scale of economic activity. ${ }^{25}$ Xenophon bears witness to this, saying:

Indeed, in most other cities it is necessary for traders to take in a return cargo, because the cities have coins that are not useful elsewhere. But in Athens, although there are many things to export which men will accept, if traders do not wish to take in a return cargo, they can also export silver, which is good merchandise. For wherever they sell it, everywhere they obtain more than its original cost. ${ }^{26}$

21. See e.g. M. I. Finley, "The Ancient City from Fustel de Coulanges to Max Weber and Beyond," Comparative Studies in Society and History 19(1977): 305-327 and M. I. Finley, The Ancient Economy, 1973.

22. E. M. Burke, "The Economy of Athens in the Classical Era: Some Adjustments to the Primitivist Model," Transactions of the American Philological Association, 122 (19741992), 199.

23. Ibid.

24. S. Dimitriev, "The rise and quick fall of the theory of ancient economic imperialism," The Economic History Review, New Series 62, no 4 (Nov. 2009), 795.

25. K. M. W. Shipton, "The Private Banks in Fourth-Century B. C. Athens: A Reappraisal," The Classical Quarterly 47, no 2 (1997), 403.

26. Xenophon, Poroi 3.2. 
Economic interests at the political level thus encouraged Athens to maintain a high demand for its coinage abroad. Such a policy echoes that of the modern United States. ${ }^{27}$ The extent of its political and economic power has made American currency a monetary standard throughout the world, potentially being a contributing cause of military conflicts with countries such as Iraq which had decided to stop trading oil in dollars prior to its invasion and "regime change" under President George Bush II in 2003. Athens was also concerned with maintaining the high quality of its monetary standard, as evidenced by Nikophon's law setting up a special department to scrutinise the purity and consistency of the Owl coins. ${ }^{28}$

Further evidence of the Athenian state's interest in promoting its economic success was that the Athenian fleet certainly did provide security as a kind of merchant marine, albeit to an uncertain extent from what can be gleaned from the sources. As trade increased, the protection of merchant shipping and exertion of some type of policing of the sea lanes would enrich individual Athenians and, indirectly, have a positive impact on the state. ${ }^{29}$ Naturally, the state took an interest in the sea-trade. The Athenian fleet worked to suppress piracy in the Aegean; but, this was not its primary role, which remained military in nature. It is unclear to what degree this protective activity was organised and on what scale. The safety of traders was apparently considered less important than national reputation during Athens' "second empire" era in the $4^{\text {th }}$ century when Hegesippus, an orator and statesman contemporary with Demosthenes, argued against a Macedonian proposal for a joint anti-pirate force on the grounds that to accept such a proposal would lower Athens' status as a sea power. ${ }^{30}$ With the exception of Hegesippus' speech, other orators' references to actions against pirates are made only in passing. ${ }^{31}$ This does not, however, imply that they did not engage in merchant marine-type activities at all-quite the contrary, it indicates that they did. As with banking, below, we must not draw too many negative conclusions due to an argument from silence. Clearly they were using the navy to suppress pirates and thus to encourage trade. This illustrates the rising importance of consumerism and the state's active interest in promoting it.

Finley and his proponents also dismissed the extent to which commercial banking took place in ancient Athens. They argued that it was a "fringe" activity only, being undertaken by slaves and metics and, as such, not a central feature of the economy as one would expect it to be if modern parallels were to be drawn to any effect. But there were banks in ancient Athens and, at least according to some surviving forensic speeches, their role was firmly at

27. Darel Tai Engen, "'Ancient Greenbacks': Athenian Owls, the Law of Nikophon, and the Greek Economy," Historia: Zeitschrift für Alte Geschichte, Franz Steiner Verlag, Bd. 54, H. 4 (2005), 362-3. 188.

28. Qtd. in R.S. Stroud, "An Athenian Law on Silver Coinage," Hesperia 43 (1974), $157-$

29. J. Ober, "Public Opinion and the Role of Sea Power in Athens, 404-322" in Naval History: the Sixth Symposium of the U.S. Naval Academy, ed. D. M. Masterson (Wilmington: Delaware, 1987), 28.

30. Pseudo-Demosthenes 7.14

31. E.g., Demosthenes 23.166ff., 58.53ff. 
the heart of the economy. ${ }^{32}$ Historians have been encouraged to minimise the importance of the private banks due to Finley's analysis in terms of Weber's theory of the "consumer city", which absorbs agrarian products, depends on rents from land and returns little by way of production. This view has exerted a notable influence over Paul Millett's analysis of banks in Lending and Borrowing in Ancient Athens. In that work he sees borrowing at interest from banks as a "last resort" of men who would prefer to "have recourse to eranoi (clubs) and other types of friendly loans." ${ }^{33}$ However, Shipton has demonstrated that Millett greatly underestimated the importance of private banks. ${ }^{34}$ She goes through speeches of the Attic orators to illustrate that the eleven extant examples "cannot be used as evidence for the actual rarity of such loans in ancient Greece". ${ }^{35}$ The allusions in the sources to customers who came to a $4^{\text {th }}$ century bank run by the ex-slave Pasion, who actually became a citizen due to his wealth and influence, demonstrate that banks recirculated wealth throughout the ancient Athenian economy and beyond. We are told that Pasion's bank specifically made loans to people "for trade". ${ }^{36}$ There is no reason a priori to assume that this was an unusual occurrence. Pasion even used the profits from his bank at the Piraeus to develop a shield manufactory, thus linking finance directly to commerce. ${ }^{37}$ Money entered the private banks from "foreigners, colonists, from citizens and metics, through trade profits, land, loans, and warfare"; it went out again to all of these and others. ${ }^{38}$ This exchange of wealth through the banks represents an ongoing cycle of deposits and loans. There was a structured, financial interchange between foreign and domestic investors from variegated strata of society. The cumulative impact of the private banks connected different areas of the ancient economy in a way that could hardly be described as "fringe" and which approached that of modern, multinational banking interests.

The arguments of Finley and others have focused especially on comparisons between ancient and modern trade. However, Burke's detailed analysis demonstrates that something like our contemporary understanding of economic activity along these lines did in fact take place which bears some striking similarities to Keynesian and other modern economic theories. As he argues, the onset of genuine commercialism had as a precondition a range of economic activities which "in no way was related to trade and

32. On what a bank amounted to, see Dem. 45.33. See too Dem. 36, 45; [Dem] 46, 49, 50, 52, 53, 59 and Isok. 17. For approaches to this oratorical evidence see E. E. Cohen, "Commercial Lending by Athenian Banks: Cliometric Fallacies and Forensic Methodology," CPh 85 (1990), 177-90; S. C. Todd, "Use and Abuse of the Attic Orators," GR 37 (1990): 159-78; P. C. Millett, Lending and Borrowing in Ancient Athens (Cambridge: Cambridge University Press, 1991), and E. Harris, Aeschines and Athenian Politics in the Age of Philip of Macedon (Oxford: Oxford University Press, 1994), ch. 1.

33. See Millett, Lending and Borrowing, 3, n. 8.

34. Shipton, "The Private Banks", 397 et passim.

35. Ibid., 402.

36. Demosthenes 49.35 .

37. J. K. Davies, Athenian Propertied Families, 600-300 B.C (Oxford: Clarendon Press, 1971), 428-30.

38. Shipton, "The Private Banks", 421. 
which was unique to the city in the second half of the fifth and first half of the fourth centuries". ${ }^{39}$ Central to that activity were the widespread and long-term cash subsidies provided by the state to its citizens, especially to those of the lowest social class, the thetes. This subsidy eventually, when combined with the impact of the devaluing of the chora (non-urban hinterland) of Attica in consequence of Spartan tactics during the Peloponnesian Wars, fundamentally altered key aspects of the socio-political ethos of Athenian society. This eventually facilitated a transition to a greater commercialism. Poorer citizens received money in subsidy from the state and they spent it, thus affecting the economy in profound ways. Burke argues that, over time, this subsidy became a political "habit" which was indulged in even under harsher economic conditions; but, he asserts that it did result in "the onset of genuine commercialism in Athens...stimulated not by the laws of a disembedded, market economy". ${ }^{40}$ Rather, this "disembedding" of the Athenian economy was made possible through the erosion of a moral principle, based on traditional status, by experiences gained from addressing economic pressures. In that sense, it is not dissimilar from the American "New Deal" and the economic prosperity that resulted from it in the modern era.

The work of Finley, Lind and others, consciously or otherwise, sought to distance ancient Athens from contemporary economic theory which others such as Meyer, von Pöhlmann and von Wilamowitz-Möllendorff had applied to it. The proponents of the primitivist/embedded model were in no small part reacting to these other attempts with recourse to a philosophical idealism that itself was somewhat dissociated from practical reality. The motivations behind the primitivist approach are difficult to pin down precisely; but, they may reflect political attitudes by elites in the $20^{\text {th }}$ century who engaged in a backlash against state intervention in economies - a backlash that had its roots in the so-called "free market", laissez faire ideology of the $19^{\text {th }}$ century, itself a euphemistic façade for the unfettered accumulation of wealth by those already wealthy, usually with the tacit support of the state. It may be too that Finley et al wanted to remove the study of ancient Greece, which had traditionally been the preserve of elites, from what they perceived as the "ugliness" of modern economic theories. Possibly they sought to discredit Keynesian theory by refusing to admit that evidence from antiquity supported its basic tenets.

It is perhaps more revealing is that scholars such as Lind and Finley, themselves elites within economically prosperous societies, sought to divorce economics from the intellectual and artistic achievements of Classical Athens with extensive recourse to other elites from that era. Plato was the son of a wealthy, aristocratic family who had greatly benefitted from his city's prosperity. Aristotle's father was court physician to the rulers of Macedon and his son also enjoyed the largess of Greece's first city. Both of those ancient philosophers eschewed the conspicuous display of wealth while, simultaneously, being the products of that wealth. We cannot discount the

39. Burke, "The Economy of Athens in the Classical Era," 201.

40. Burke, "The Economy of Athens in the Classical Era", 225. 
role of such ephemera as chance and fortune, but these ancient philosophers arguably could not have achieved their successes in a poorer society.

With these points in mind, it does seem clear that the ancient Athenian state was actively interested in its own economic prospects and intervened at the micro- and macroeconomic level to ensure them. It also seems clear that the Athenian Empire of the $5^{\text {th }} / 4^{\text {th }}$ centuries benefitted from this economic interest at state level and that not only did its citizens experience the positive influences of state subsidies, these in turn promoted further economic growth that coincided with that polis' apex on the world stage as a hegemonic and economic superpower within the albeit limited confines of the Mediterranean world at that time. Historic causality is difficult to prove with regard to long-term trends and others will, no doubt, continue to debate these points. However, it does seem that Classical Athens repudiates both Keynes' theories as well as the application of those and other modern, economic theories to the ancient past when our evidence makes it possible to do so.

\section{Bibliography}

Burke, E. M. "The Economy of athens in the classical era: some adjustments to the primitivist model." Transactions of the American Philological Association, 122 (1974-1992), 199-226.

Cohen, E. E. "Commercial lending by Athenian banks: Cliometric Fallacies and Forensic Methodology." CPh 85 (1990), 177-90.

Corby, G. "Ancient Greek insurance scams." Last modified February 5, 2009, http://bit.ly/2Blj1aP.

Davies, J. K. Athenian Propertied Families, 600-300 B.C. Oxford: Clarendon Press, 1971).

de Ste. Croix, G. E. M. "Notes on Jurisdiction in the Athenian Empire." Classical Quarterly, N.S. 11.1(1961): 94-112.

Dimitriev, S. "The rise and quick fall of the theory of ancient economic imperialism." The Economic History Review, New Series 62, no 4 (Nov. 2009), 785-801.

Engen, D. T. "'Ancient Greenbacks': Athenian Owls, the Law of Nikophon, and the Greek Economy." Historia: Zeitschrift für Alte Geschichte, Franz Steiner Verlag, Bd. 54, H. 4 (2005), 359-381.

Finley, M. I. The ancient economy. Berkeley: University of California Press, 1973.

Finley, M.I. "The ancient city from fustel de coulanges to Max Weber and beyond." Comparative Studies in Society and History 19 (1977): 305-327.

Hansen, M. H. Polis: an introduction to the ancient Greek city-state. Oxford: Oxford University Press 2010.

Harris, E. Aeschines and Athenian politics in the age of Philip of Macedon. Oxford: Oxford University Press, 1994.

"Keynesian Economics," Investopedia, http://bit.ly/2zaY1Sr.

Lind, L. R., "Economic man in ancient Athens." The Classical Journal 35, no. 1 (Oct. 1939): 27-38.

Millett, P. C. Lending and borrowing in Ancient Athens. Cambridge: Cambridge University Press, 1991.

Moore, K. R. Sex and the second-best city, sex and society in the Laws of Plato. Routledge: New York, 2005. 
Nafissi, M. "Class, embeddedness, and the modernity of ancient Athens." Comparative Studies in Society and History 46, no 2 (Apr., 2004): 378-410.

Neary, J.P., and Stiglitz J.E. "Toward a Reconstruction of Keynesian Economics: Expectations and Constrained Equilibria." The Quarterly Journal of Economics, 98 Supplement (1983), 199-228.

Ober, J., "Public opinion and the role of sea power in Athens, 404-322." Naval History: the Sixth Symposium of the U.S. Naval Academy, edited by D. M. Masterson, 26-31. Wilmington, Delaware: 1987.

Shipton, K. M. W. "The private banks in fourth-century B. C. Athens: A reappraisal." The Classical Quarterly 47, no 2 (1997), 396-422.

Stroud, R.S. "An athenian law on silver coinage." Hesperia 43 (1974), 157-188.

Todd, S. C."Use and abuse of the attic orators." GR 37 (1990): 159-78.

von Pöhlmann, R. The history of the social question and of socialism in the ancient World. Munich: 1893-1901. 
